\title{
Root and crop growth of oats as affected by the length of periods of high water-table
}

\section{J. J. Schuurman}

Institute for Soil Fertility, Postbus 30003, 9750 RA Haren - Gr., the Netherlands

Accepted: 7 September 1979

Key words: shoot growth, root weight, rooting depth, nodal roots

\section{Summary}

The influence of the duration of a high water-table upon root and shoot growth of oats in an early growth stage was studied. It was found that root weight, depth of rooting and number of nodal roots with a length of less than $10 \mathrm{~cm}$ reacted favourably upon a low water-table. In this experiment shoot growth, however, hardly reacted to better root growth. This means (in this case) that the plants in this experiment with restricted root growth could absorb water and nutrients as well as those with larger root systems. The fertilization of the top $0-25 \mathrm{~cm}$ of soil will have been an important factor in this respect.

\section{Introduction}

The effect of a permanent high water-table in the soil on root development has already been studied in the preceding century by von Seelhorst \& Tucker (1898). Other authors have reported about this problem afterwards (Elliott, 1924 with maize; Könekamp and König, 1929 with a grass-clover mixture; Goedewaagen, 1942 with various crops; Goedewaagen, 1952 with strawberries; Schuurman, 1955 with winter wheat; Schuurman \& Goedewaagen, 1955 with potatoes; Goedewaagen and Schuurman, 1956 with grassland; Wiersma, 1959 with various crops; Minderhoud, 1960 with grassland; Yu, Stolzy \& Letey, 1969 with barley, maize, sunflower, tomato and wheat; Ralston \& Daniel, 1972 with creeping bent grass (Agrostis palustris Huds.). The general conclusion that can be drawn from the majority of the investigations is that - unless specific conditions prevail - root growth of many plants ends at best just above the water-table or in many cases even at some distance above it. Unpublished data on oats, barley, perennial rye grass, Poa pratensis, Poa trivialis and Phleum pratense confirm this conclusion. It may be taken for sure that hampering of root growth above a water-table is caused by shortage of oxygen.

The only marked exception is given by Könekamp \& König, who found roots 
of a grass-clover mixture, growing at a water-table of $40 \mathrm{~cm}$ below soil surface, penetrating to a depth of 90 to $112.5 \mathrm{~cm}$, depending upon soil type. Root penetration, however, was deeper with a water-table of $130 \mathrm{~cm}$, indicating that it was hampered by the high water-table. It is probable that root penetration in the latter case was caused by experimental conditions favouring oxygen content in the ground water. The same may have played a part in the experiment of $\mathrm{Yu}$, Stolzy \& Letey (1969).

Little is known, however, about the influence of the duration of periods of high water-table during the early stages of growth of plants, even though this is an important practical problem in relation to subirrigation. Furthermore, in the Netherlands the situation is generally such that there is a high water-table during winter that sinks during spring to a considerable depth. Often the water-table is high at the moment of sowing and remains so during periods of various lengths afterwards. This implies that a long period is a quite common phenomenon for winter-sown crops and that the length of the period decreases according to later sowing. Hence, the question arises how the length of a period of high water-table affects root development and accordingly crop growth and yield. This question is important because restricted root growth under practical conditions generally results in decreased yields.

\section{Materials and methods}

The experiment was carried out with homogeneous artificial profiles, consisting of sand with a humus content of $4.5 \%$ and a $\mathrm{pH}$ of 5.5 , that were built up in PVC cylinders as has been described previously (Schuurman \& Goedewaagen, 1971). The layer from $0-25 \mathrm{~cm}$ was mixed with fertilizers. The pore volume was $47 \%$. This means that root growth was not inhibited by density of the soil. The crop used was oats, one plant per cylinder. In the experiment the following treatments were present:

1) a permanent water-table of $40 \mathrm{~cm}$ below ground level;

2) an initial water-table of $40 \mathrm{~cm}$ below ground level that was lowered 10 days after sowing to a depth of $80 \mathrm{~cm}$. This was also done after $15,20,25,30,35$, 40,45 and 52 days, respectively;

3) a permanent water-table of $80 \mathrm{~cm}$ below ground level.

All plants were harvested simultaneously at the ripening stage, about three weeks after initial flowering. Root weights were determined in layers of $10 \mathrm{~cm}$.

\section{Results}

\section{Number of nodal roots per plant}

These data are given in Fig. 2A. Even though there was some variability among the numbers, the reaction of the plant to a decrease in duration of the high water-table can be stated as a slow increase in total root number. In other words: the rate in which water availability for the plant was restricted and oxygen supply was improved was determining the total nodal root numbers. In this respect the 


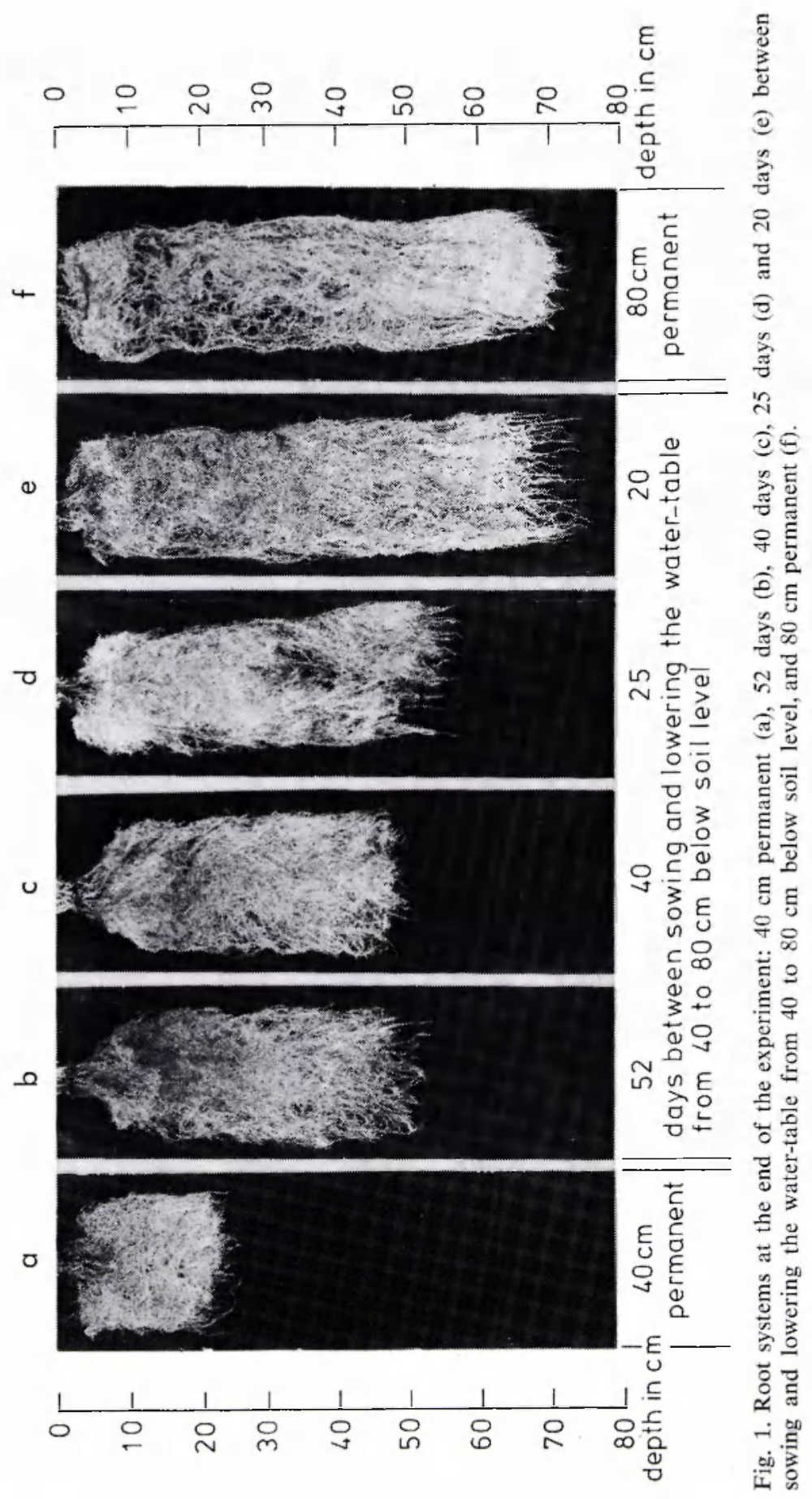

Neth. J. agric. Sci. 28 (1980) 
plants on the profiles with a permanent high water table show the most pronounced response. Roots have been divided arbitrarily in those longer than $10 \mathrm{~cm}$ and shorter ones on the assumption that the longer roots have been more important for the plant than the shorter roots. It is peculiar that now a distinctively different pattern was found, in so far that the longer roots of the plants at the permanent low water-table tended to decrease in number. The differences in duration of high water-table from 45 to 10 days did not significantly affect the number of longer roots. A longer duration probably caused a decrease parallel with total numbers.

\section{Maximum root penetration}

In Fig. 1 photographs of root systems of 6 out of 11 treatments give general evidence about differences in root penetration. Fig. $2 \mathrm{~B}$ shows that root penetration with a permanent water-table at a depth of $40 \mathrm{~cm}$ ended at a certain distance above this water-table. This is in accordance with earlier results. Root penetration was most inhibited by the permanent high water table, much less by a duration of the high water-table from 52 to 25 days, and again less by a duration from 20 to 10 days. Root penetration was deepest with a permanent water-table of $80 \mathrm{~cm}$ below ground level.

\section{Root weights}

Root weights tended to increase concurrent with decreasing water availability and improved oxygen supply (Fig. 2C). This was also concomitant with deeper penetration and increasing number as might be expected. More or less as in root penetration four groups may be distinguished in the root weights:

1. permanent high water-table $(+52$ days period)

2. (52) 45 to 25 days high water-table

3. 20 to 10 days high water-table

4. permanent low water-table.

\section{Root distribution}

These data are shown in Fig. 3. The highest percentage present in the top layer of $0-10 \mathrm{~cm}$ was found in the profile with the permanent high water-table. This percentage dropped sharply in the profile with $\mathbf{5 2}$ days high water table and then more or less gradually to the shortest period and probably from this to the permanent low water-table. In the layer from $10-20 \mathrm{~cm}$ the highest percentages were found with 40 or 52 days of high water-table, percentages decreasing in the direction of drier profiles as well as the wettest one. In the $20-30 \mathrm{~cm}$ and $30-40 \mathrm{~cm}$ layers a similar result was found with the maximum shifting to drier profiles. Below this depth significant amounts of root were only present in the four drier profiles, so that it can be concluded, as was found by Goedewaagen (1942), that shallow root systems had a higher percentage of root weights in the topsoil.

\section{Shoot growth}

In Fig. 4 data are given on shoot weights and lengths. Shoot weights did not differ 


\section{J. J. SCHUURMAN}
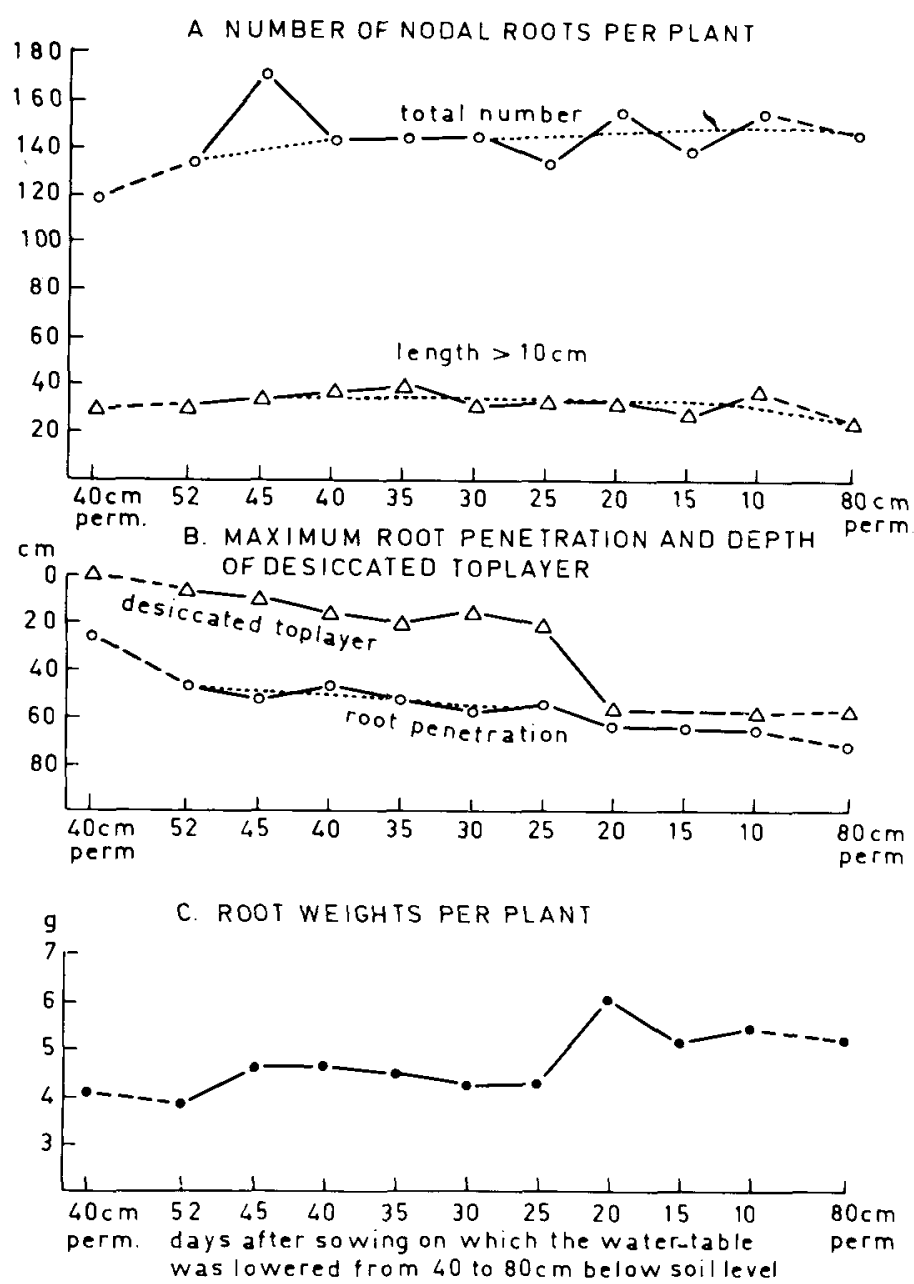

Fig. 2. Effect of (length of periods of high) water-table on (a) number of nodal roots per plant, (b) maximum root penetration and depth of desiccated top layer, and (c) root weight per plant.

significantly. Only the shoot weight found with the permanent high water-table was higher than in the other treatments. It might be assumed that the weights of the driest three profiles were possibly lowest. The maximum length was hardly affected (Fig. 4B).

\section{Shoot/root ratios}

As to this factor plants can be divided in three groups (Fig. 5). The highest shoot/ root ratio was found with the two wettest profiles. Then it decreased rather suddenly to lower values with the profiles having a high water-table from 45 to 
ROOT WEIGHTS PER LAYER IN \% OF TOTAL WEIGHTS

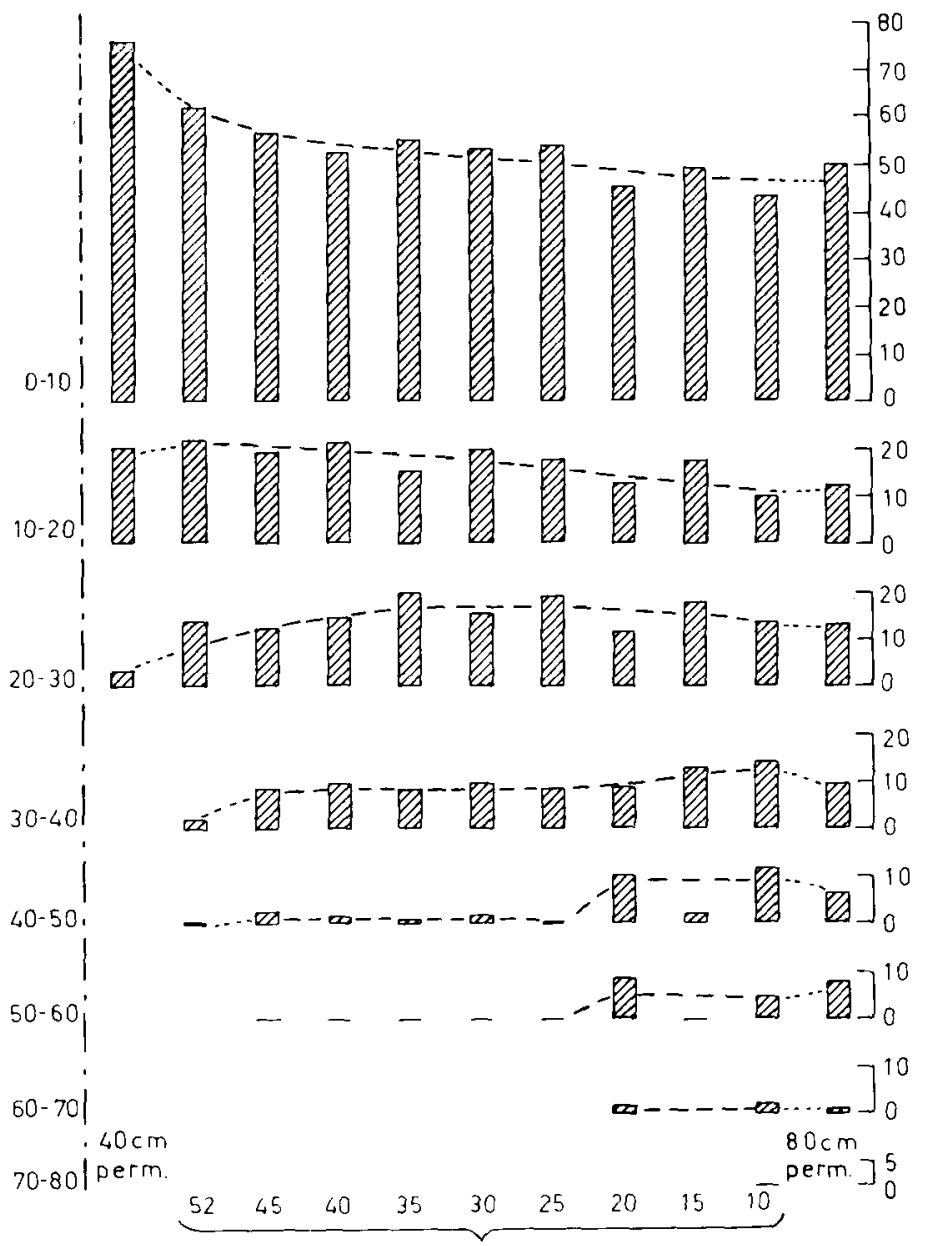

Fig. 3. Effect of water-table on root distribution.

25 days. Another drop followed in the drier profiles having 20 to 10 days with a high, and a permanent low water-table.

\section{Discussion}

The influence of the duration of a period of high water-table in an early growth stage of oats on root and shoot development of this crop was studied. 


\section{J. J. SCHUURMAN}
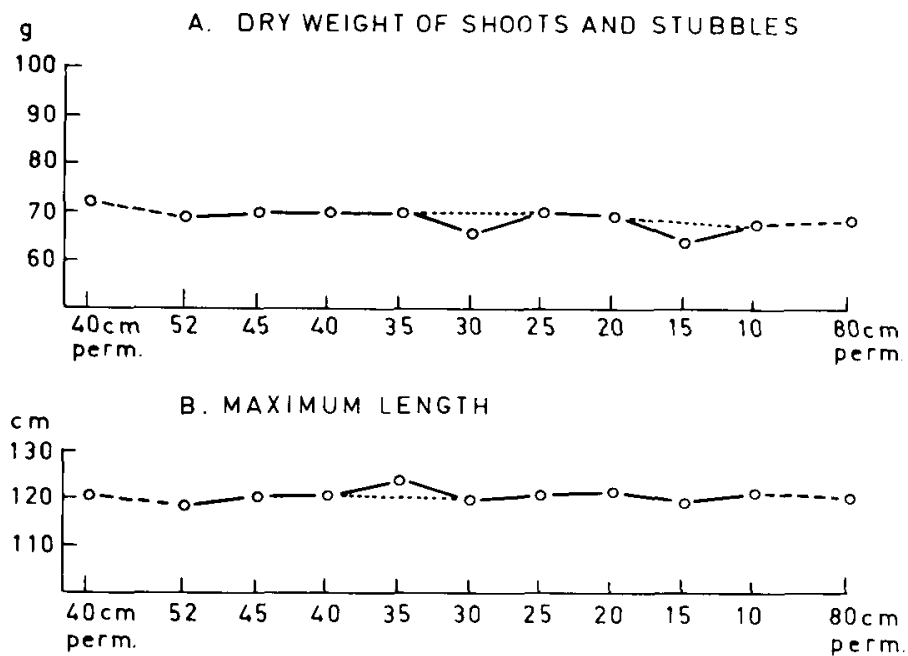

Fig. 4. Effect of water-table on (a) dry weight of shoots and stubbles, and (b) maximum length.

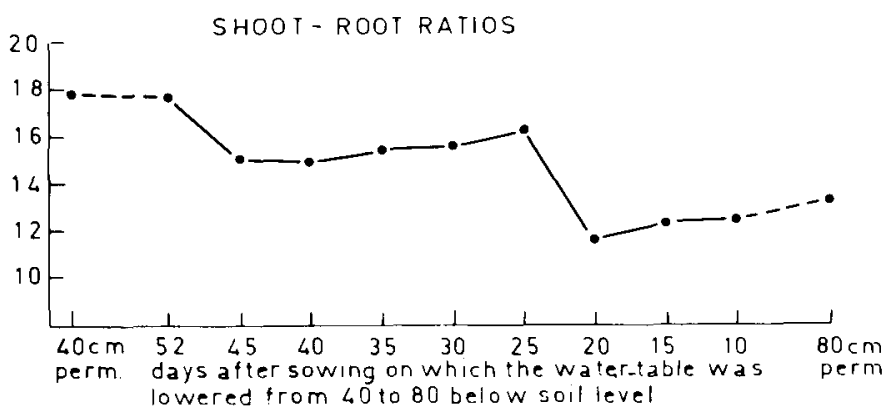

Fig. 5. Effect of water-table on shoot/root ratios.

To this end data of the following characteristics of the root system were collected:

1) the image of the root system;

2) the maximum rooting depth;

3) the total number of nodal roots and the number of these roots longer than $10 \mathrm{~cm}$;

4) total root weights per plant;

5) the percentual distribution of the roots in the profile, calculated from the total root weight.

For information on the shoot, the following characteristics were collected:

1) the weight of the oven-dried shoots;

2) the maximum length. 
From the shoot and root weights the shoot/root ratios were calculated.

At the end of the experiment desiccation depth of the soil was ascertained by visual observation.

Root weight appeared to increase concomitant with decreasing duration of the high water-table (Fig. 2C). This weight increase, however, was not gradual but by leaps, namely when the duration of the high water table decreased from 52 to 45 days and from 25 to 20 days. It must be assumed that these two changes indicate sensitive periods in the lifespan of the plants. The increase in root weight will, at least partly, have been caused by the longer roots and the higher number of nodal roots (Fig. $2 \mathrm{~B}$ and $2 \mathrm{~A}$ ).

Under practical conditions higher root weight, deeper rooting and more roots are considered as favourable characteristics for shoot growth. Shoot growth in this experiment, however has hardly reacted in accordance with the differences found. An exception may be made for the permanent high water-table, where the highest shoot weight was recorded (Fig. 4), but also this difference was not significant. The only possible explanation, within the scope of the collected material, is that all plants have been able to absorb sufficient minerals, due to the fertilization of the $0-25 \mathrm{~cm}$ layer and did not suffer considerably from shortage of water, although the depth of desiccation of the soil in the cases of the plants growing on soils with long periods with low water tables may be seen as an indication for increasing difficulties in water uptake (Fig. 3). The conclusion that can be drawn from the shoot-root ratios is also that the plants with the long periods with a high water table were in a more favourable position than the others (Fig. 5). This confirms earlier findings of L. K Wiersum (personal communication) and Schuurman (1971).

\section{References}

Elliott, G.R.B., 1924. Relation between the downward penetration of corn roots and water level in peat soil. Ecology 5: 175-178.

Goedewaagen, M. A. J., 1942. Het wortelstelsel der Landbouwgewassen. 's-Gravenhage, Algemene Landsdrukkerij, $173 \mathrm{pp}$

Goedewaagen, M. A. J., 1952. Grondwaterstand en beworteling der gewassen. Versl. tech. Bijeenk. 1-6: 65-82.

Goedewaagen, M. A. J. and J. J. Schuurman, 1956. Root development on grassland with special reference to water conditions of the soil. Proc. 7 th int. Grassland Congr., Session 1, Paper 3: 1-12.

Könekamp, A. \& T. König, 1929. Untersuchungen über den Einfluss des Grundwassers auf die Entwicklung eines Kleegrasgemisches. Landw. Jahrb. 69: 224-232.

Kramer, P. J., 1949. Plant and soil water relationships. McGraw-Hill, New York, 347 pp.

Minderhoud, J. W., 1960. Grasgroei en grondwaterstand. Proefschrif $t$, Landbouwhogeschool Wageningen, $199 \mathrm{pp}$.

Ralston, D. S. \& W. H. Daniel, 1972. Effect of temperatures and water table depth on the growth of creeping bentgrass roots. Agron. J. 64: 709-713.

Schuurman, J. J., 1955. De wortelontwikkeling van wintertarwe in klei-zandprofielen in betonnen buizen bij ongelijke kleilaagdikte, grondwaterstand en fijnheidsgraad van het 


\section{J. J. SCHUURMAN}

zand. In: De wortelgroei in gronden, bestaande uit een bovengrond van klei en een ondergrond van zand. Versl. landbouwk. Onderz. 61.7: 122-135.

Schuurman, J. J., 1971. Effects of supplemental fertilization on growth of oats with restricted root development. Z. Acker- u. Pfl Bau 133: 315-320.

Schuurman, J. J. \& M. A. J. Goedewaagen, 1955. De wortelontwikkeling van aardappelen in de Bommelerwaard op rivierklei met een zandige ondergrond in verband met de dikte van de kleilaag, grondwaterstand en bemesting. In: De wortelgroei in gronden, bestaande uit een bovengrond van klei en een ondergrond van zand. Versl. landbouwk. Onderz. 61.7: $72-78$.

Schuurman, J. J. \& M. A. J. Goedewaagen, 1971. Methods for the examination of root systems and roots. Pudoc, Wageningen, $86 \mathrm{pp}$.

Shaw, B. T., 1952. Soil physical conditions and plant growth. Agronomy, a series of monographs, Vol. 2. Academic Press, New York, 491 pp.

Tucker, M. \& C. von Seelhorst, 1898. Der Einfluss welchen der Wassergehalt und der Reichtum des Bodens auf die Ausbildung der Wurzeln und oberirdischen Organe der Haferpflanzen ausübt. J. Landw. 46: 52-63.

Wiersma, D., 1959. The soil environment and root development. Adv. Agron. 11: 43-51.

Yu, P. T., L. H. Stolzy \& J. Letey, 1969. Survival of plants under prolonged flooded conditions. Agron. J. 61: 844-847. 